\title{
FROM MAJOR TO MINOR: A READING OF "AS I EBB'D WITH THE OCEAN OF LIFE"
}

\author{
R. W. FRENCH
}

ONE OF THE ENDURING FAscinations of Leaves of Grass is its constant movement through shifting moods. Continually the book turns on itself, with frequent changes and self-corrections; there is nothing it asserts that it does not at some time deny. It is as full of doubt as it is of faith. Every great Whitman theme is questioned, rejected, reasserted, and questioned again: trust in nature, love of humanity, assertion of the physical, faith in ultimate order, authority of the self, belief in the powers of poetry - these and others are confidently celebrated on some pages and bitterly dismissed on others.

"As I Ebb'd with the Ocean of Life" occupies a crucial place in Whitman's history of doubt and faith, as it moves from a desperate turning against the past to a new awareness, tempered by experience. Starting in anguished rejection, it must find a way to begin again, to go on with life, and in the restrained realism of its perceptions it becomes particularly modern. The poem makes no grand claims, asserts no overwhelming universal truths, relies on no supernatural supports; like Wordsworth, Whitman descends to "words / Which speak of nothing more than what we are."1 The bardic voice has disappeared, and the barbaric yawp is subdued to halting phrases. The poem collapses into fragments, bits and pieces, the insignificant debris of life; but that is not where it ends. Instead of falling into the silence of despair and hopelessness - as well it might-it takes the more difficult and courageous route of building on the harsh reality it perceives. If there is a heroism of ordinariness, this poem exemplifies it; and the challenge that it confronts, finally, is that of Frost's Oven Bird: "what to make of a diminished thing." That challenge of course haunts much twentieth-century literature.

The poem begins with the poet walking along the beach, "musing," as he says, "late in the autumn day, gazing off southward." 3 The hour and season combine to encourage reflection (much as they do, incidentally, in those other late-afternoon, autumnal poems of contemplation and reassessment, "Andrea del Sarto" and "The Love Song of J. Alfred Prufrock"). While the poet walks, complacent in the pride he feels in his art, he is "seiz'd by the spirit that trails in the lines underfoot. ..." This spirit leads him into a state of acute depression marked by deep feelings of guilt, inadequacy, and failure. He sees the 
debris along the shore, the cast-off leavings from the ocean, and in them he sees emblems of his own insignificance. "I too," he discovers, "but signify at the utmost a little wash'd-up drift, / A few sands and dead leaves to gather, / Gather, and merge myself as part of the sands and drift."

The suddenness of the change from pride to depression is surprising, but it is not unbelievable, nor even unusual. Whitman's use of the word "seiz'd" is absolutely right; as William James has noted, "The sudden and explosive ways in which love, jealousy, guilt, fear, remorse, or anger can seize upon one are known to everybody."4 In a footnote to this sentence James quotes an individual subjected to an unexpected transformation of mood: "One night I was seized on entering bed with a rigor, such as Swedenborg describes as coming over him with a sense of holiness, but over me with a sense of guilt." Significantly, both James and this nameless individual use the same verb - "to seize"-as Whitman in this poem, a work much concerned with guilt. ${ }^{6}$ In such a mood, the individual, helpless, is held captive.

The poet had been seeking "types" (metaphors, likenesses, correspondences), and he finds them, although they turn out to be not what he had expected. He looks at the world of nature about him and sees "Chaff, straw, splinters of wood, weeds, and the sea-gluten, / Scum, scales from shining rocks, leaves of salt-lettuce, left by the tide . . . ." The objects are wholly insignificant; there is no glorification here, no sense of infinitude, as there is, for example, in the "mossy scabs of the worm fence, heap'd stones, elder, mullein and poke-weed" of "Song of Myself," line 98. In an earlier apprehension the ordinary could be perceived as "limitless," but that vision will no longer serve. Now we have only debris, the ocean's junk, seen as itself and nothing more. Like Wordswoth in the Intimations Ode, the poet of "As I Ebb'd" must deal with a loss of glory. The world is not what it was; the question now is to find a response to redeem such loss.

The second section begins to resolve that question by asserting similitude. It is a commonplace that Romantic poets see themselves reflected in the images of nature; the outer life mirrors the inner-or, rather, the inner life creates the outer. ${ }^{7}$ Falling into depression, the poet easily finds objects to fit-even to exacerbate-his mood. As noted above, he sees himself in the debris washed up along the beach-"I too but signify at the utmost a little wash'd-up drift"-and, in the great passage that follows, he rebukes himself for daring to open his mouth; he dismisses his" words as "all that blab" and condemns himself for never having known his true identity:

O baffled, balk'd, bent to the very earth,

Oppress'd with myself that I have dared to open my mouth, 
Aware now that amid all that blab whose echoes recoil upon me I have not once had the least idea who or what I am,

But that before all my arrogant poems that real Me stands yet untouch'd, untold, altogether unreach'd,

Withdrawn far, mocking me with mock-congratulatory signs and bows,

With peals of distant ironical laughter at every word I have written,

Pointing in silence to these songs, and then to the sand beneath.

All, he discovers, has been vanity and self-deception. The tone is bitter; the passage has to be one of the more painful that any poet has ever written, for, undermining from within the poet's confidence in himself and his art, it leaves him exposed and helpless, a mere object of derision. Whitman sees his authentic self - "the real Me"-standing off in the distance, mocking the poet who wrote all those "arrogant" poems - "arrogant" because the poems came out of an ignorance assumed to be knowledge. They are seen now as deceitful and dishonest, the work of a fake, a pretender, an imposter; they have no substance and no truth to them. The poet now realizes that he did not know himself, and he did not know nature; how could he presume to write? The collapse is total and devastating; we see the poet consumed by self-ridicule and the anguished knowledge of failure. ${ }^{8}$

At the end of the second section the poet is despondent; what is surprising is that the poem continues, as there is good reason for it to end at this point. Why go on? The poet finds no meaning or value in life; the extremity of his language - as when he says "I have not once had the least idea who or what I am" and "I have not really understood any thing, not a single object"-indicates clearly the force of his mental depression. ${ }^{9}$ His violent self-rebuke has left him incapacitated, bereft of energy and confidence. The poem at this point would seem to have dropped into a pit from which it cannot extricate itself. To make matters worse, this section ends with Nature itself castigating the poet for daring to sing his poems: "Nature here in sight of the sea taking advantage of me to dart upon me and sting me, / Because I have dared to open my mouth to sing at all." Such stern rebuke, from such a source, would seem to leave no answer possible but penitent silence-or at most, barely audible words of contrition and apology, as in the Book of Job, where the Voice from the Whirlwind, comparable to Nature in Whitman's poem, overwhelms Job into submission and self-rebuke. Like Whitman, Job condemns himself even for speaking: "I will lay mine hand upon my mouth. Once have I spoken, but I will not answer: yea, twice; but I will proceed no further."10

As Job is forced into apology ("I abhor myself, and repent in dust and ashes"), " so is Whitman. The poet had called his poems "arrogant"; now, in the third section of the poem, he turns away from the arrogant past and becomes submissive, humble, pleading. No longer pretending to self-sufficiency, he seeks union and reconciliation. Of the 
opening ten lines of this section, seven, it should be noted, have to do with identity: lines 35-37 (the opening verse of the section) assert an identity with "You oceans both," and lines 40-44 connect the poet to Paumanok, the land, the "father" as opposed to the "fierce old mother," the ocean. Significantly, in this section the poet repeats, with slight variations, what he had said in the previous section ("I too but signify at the utmost a little wash'd up drift" is followed by "I too am but a trail of drift and debris"); but the meanings are different, for the tone has changed. The voice of section 2 is shocked, overwhelmed, stricken with pained discovery, while the voice of section 3, as it comes to accept the identification, is muted and restrained. The anguish has gone, to be replaced by chastened recognition; the outburst has become a murmur.

The initial perception of identity is not rejected; it is, rather, seen in an altered light. The "little shreds" of debris do indeed stand for the poet and the two oceans, the ocean of life as well as the "fierce old mother." To see these connections is to gain in self-knowledge, and in so doing to move from arrogance to humility; as T.S. Eliot wrote in "East Coker," "In order to arrive at what you do not know / You must go by a way which is the way of ignorance." 12 The poet can now with equanimity see himself as drift and debris; that is what it means to be human. To wish to be more than that is to wish to be more than human, to live in an illusion of grandeur, to be willfully blind. The lesson is that of Job, who found his true being in learning his insignificance; it was a gain that could come only through loss. To quote Eliot again: "In order to possess what you do not possess / You must go by the way of dispossession." 13

In the third section of "As I Ebb'd," the poet achieves humility by recognizing his place in the scheme of things. He is now able to plead submissively, yet passionately, with the father: "Kiss me my father, / Touch me with your lips as I touch those I love, / Breathe to me while I hold you close the secret of the murmuring I envy." As is often pointed out, Whitman generally shows little sympathy for fatherfigures; the best-known such figure in his poetry, for example, is the distant and fearsome father of "There Was a Child Went Forth," a representation of power, injustice, and oppression. It is a sign of the new-found humility in this poem that the poet can plead as he does with the "father," the land. This is not to say, of course, that Paumanok is Walter Whitman, Sr., in any obvious way, but, rather, that the poet can now approach the "father" in a spirit of submission. He speaks out of incompleteness, knowing his intense needs for recognition, for comfort, for love, and for the reassurance of the "secret" that he assumes the father must know. The sense of personal insufficiency behind these needs might be compared with the jauntily confident position taken in 
lines 989-990 of "Song of Myself" where it is the earth, not the poet, that appears needy: "Earth! you seem to look for something at my hands, / Say, old top-knot, what do you want?"

Strangely, the poet gets no answer from the land, the "father"-a potentially disconcerting turn of events for the poet who once found answers everywhere, who could "hear and behold God in every object."14 Still, the answer does not come; what the poet hears is murmuring, and moaning, and crying, but this time there is no voice to give him superior knowledge, no word from the sea, no mystic carol of death. ${ }^{15}$ The lack of response might be seen as cause for despair, but what we have at this point is not despair, but resignation. The silence is itself a lesson that the poet must learn: for there is no "secret" that he can understand. Like Job, he must come to recognize that the universe is ultimately mysterious, beyond human knowledge. ${ }^{16}$ Its grandeur dwarfs human enterprise and human thought; it has nothing of comfort or consolation to whisper to him. He must learn-and it is a difficult lesson for the poet who proclaimed his divinity in "Song of $\mathrm{My}$ self" - that he is not a god, that man is not the measure of things, and that the universe does not exist for anyone's particular good. Nature in this poem is clearly not the beneficent creation of "Song of Myself"; its music is a "sobbing dirge," and, as represented by the sea, it is threatening and potentially destructive. In "Song of Myself," by contrast, the sea was a lover:

You sea! I resign myself to you also-I guess what you mean,

I behold from the beach your crooked inviting fingers,

I believe you refuse to go back without feeling of me,

We must have a turn together, I undress, hurry me out of sight of the land,

Cushion me soft, rock me in billowy drowse,

Dash me with amorous wet, I can repay you. (448-453)

In "As I Ebb'd" the sea is not lover but mother (as of course it is also in "Out of the Cradle Endlessly Rocking"). What's more, it is a "fierce old mother" that moans, "Endlessly crying" for its "castaways"; it rustles up "hoarse and angry" against the poet's feet. The representation is ominous and uncomfortable: a figure of sorrow, lamentation, and sullen hostility. With such there can be no full reconciliation; there can be recognition and acceptance, but hardly love. One must keep one's distance. Thus in the final section the poet dismisses the sea by recognizing that she is to continue in her ways ("Cease not your moaning you fierce old mother"); one must live with the world as it is, however one might wish that it could be otherwise. The fact is that the "ocean of life" is harsh: it has "castaways" that must be mourned; and the music of nature, as noted above, is "a sobbing dirge." 
The dirge that the poet hears is music of unrelieved sadness, a true song of death. In this poem death is not to be praised or celebrated, as it is, say, in "Out of the Cradle Endlessly Rocking" or "When Lilacs Last in the Dooryard Bloom'd," and it is not to be dismissed, as it is in line 1289 of "Song of Myself" ("And as to you Death, and you bitter hug of mortality, it is idle to try to alarm me)"; it is simply not available as consolation in any form. Death in "As I Ebb'd" offers no special insights, no entrance into eternity, no enduring calm; it is a way of nature, no more: all life dies, and that is a fact. The view of death that the poem presents-significantly confined to parentheses-is appropriately graphic and clinical: "(See, from my dead lips the ooze exuding at last, / See, the prismatic colors glistening and rolling)". There is nothing to celebrate here, and it is useless to protest. Death and life, both must be endured.

The fourth section, then, gives us acceptance, if not reconciliation. The poet opens with imperatives ("Ebb," "Cease not," "Endlessly cry," "Rustle not up so hoarse"), just as he did in the final section of "Crossing Brooklyn Ferry," another poem that moves toward acceptance, although in a different tone. Let things be as they are; everything is in its place. Whatever may be the situation out there, in the world of nature, the poet has achieved his peace; he holds no resentment, no anger ("I mean tenderly by you and all"). He can now turn back to himself, this time without bitter self-reproach, and he can go about his business: "I gather for myself and for this phantom looking down where we lead, and following me and mine. ...."

And who is this "phantom"? Most probably, the phantom who looks down is the same as the unidentified "You up there walking or sitting, / Whoever you are" in the closing lines; that is, the reader, who appears a number of times in Whitman's poems as "whoever you are" or some such phrase. ${ }^{17}$ The reference is important, for it marks the conclusion of the poet's restoration to his calling. As much as any poet who ever wrote, Whitman insisted on the necessity of the reader to complete the poem; ${ }^{18}$ and among the most prominent characteristics of Leaves of Grass is the frequency with which Whitman addresses or otherwise refers to his reader: often he seems conscious of someone looking over his shoulder. ${ }^{19}$ What is striking about "As I Ebb'd" is that the poet, having at the start of the poem given up all claims to authority by recognizing that he had never known himself or understood anything, at the end of the poem is prepared to re-assert his claims on a reader. This is a poem that abandons its audience, only to gain it again, on an altered basis; for the poet has to move through the blindness of pride, and then through the blindness of collapse, before he can achieve regeneration and discover that he still deserves an audience. By passing through the darkness, he has gained illumination; though chastened and subdued, 
he is ready to begin again. Having called out to the land, and to the sea, without an answer, he now calls out to his reader, knowing that there will be no response except, perhaps, at some uncertain date, to the poem itself.

Reconciled to his calling, he remains a poet, a gatherer along the shore, collecting his fragments. In a brilliant fusion at the close, Whitman brings together the debris of the beach-"loose windrows, little corpses, / Froth, snowy white, and bubbles"-and his poems, those cast-off and disconnected utterances "Buoy'd hither from many moods, one contradicting another, / From the storm, the long calm, the darkness, the swell." Poems are recognized for what they are, fragments tossed up from the sea, from the mysterious depths of creation, perhaps no more than "A limp blossom or two"; for the poet must learn to accept insignificance, his own as well as that of his creations. Not without pain, he is coming to terms with his own humanity, which means the relinquishing of claims to grandeur; now he ceases to be the bard, since he has lost all bardic authority. ${ }^{20}$

"As I Ebb'd" thus shows a poet pulling back, reducing his claims, re-establishing the basis of his work. By the end of the poem he has abandoned his illusion of self-sufficiency, for he knows that life is not a matter of conscious control, no more than the debris scattered along the beach; he and all that pertains to him, he realizes, are "capricious, brought hither we know not whence. ..." As Ecclesiastes long ago noted, the two operative forces in this world are time and chance. ${ }^{21}$ "Song of Myself," rejecting chance, had insisted that time was purposeful: "Immense have been the preparations for me. . . . All forces have been steadily employ'd to complete and delight me. . . ."22 In "As I Ebb'd," however, that sense of order is abandoned. One must surrender to the randomness of things; that is the only way to establish a proper relationship to the universe as it actually is. The poet is clearly ready by the end of his poem to trust to the workings of chance. Let the poems, the fragments, as "capricious" as the human life that formed them, be "drifted at random"; in time they will find their way to the presence of some audience yet unknown: "We, capricious, brought hither we know not whence, spread out before you, / You up there walking or sitting, / Whoever you are, we too lie in drifts at your feet."

"As I Ebb'd," then, works toward a new realism; it marks a farewell to illusion and self-deception, and it sets out to begin life again as it re-establishes a relationship to the world-or, perhaps, as it establishes for the first time a relationship to the bleak world it has discovered. ${ }^{23}$ It is essential to an understanding of this poem to recognize its bleakness and not diminish it by reading other Whitman poems into it; surely, for example, it is too much to say that "As I Ebb'd" shows "reassurance in the certainty of the ultimate goal of mystic 
evolution." 24 There is nothing of mystic evolution in the poem, and no sense of purposefulness. ${ }^{25}$ Things happen as they happen to; that is all. What's more, there is in "As I Ebb'd" no benevolent God, leaving "baskets cover'd with white towels swelling the house with their plenty"; 26 there is no joyous nature, no assertion of order, no celebration of humanity (for humanity as it appears in the figure of the poet is exposed, needy, and vulnerable). Not even death, as has been noted, is offered for consolation and redemption. Where then does the poem leave us?

Like the Book of Job, it appears to be something of a test case. Suppose that all the illusions of a benevolent and just order were removed: what then? What then would give meaning and purpose to life? "As I Ebb'd" leaves us with fragments-Whitman even uses the word in line 61 - to shore against our ruins. ${ }^{27}$ Along with the fragments, however, we have human consciousness and a voice to articulate perceptions; for even Job, after all, retained these, and with them he transformed his sufferings into language of the highest art and power. It would be too simple to say that "As I Ebb'd" is "about" poetry, as it is about much else beside; but certainly the theme of poetry is central, for "As I Ebb'd" begins with the poet in his pride and ends with the poet in his humility, and the last lines constitute an offering to a distant reader. The poem takes us into spiritual collapse; but it is poetry that provides the way out of despair by suggesting the redemptive powers of art. It is, the poem implies, the poet's obligation to write of perceived reality, however poor it may appear; surely art may find in that imperative sufficient purpose and justification. As Whitman noted in the 1855 Preface-although perhaps not realizing at the time the directions in which his explorations would lead - "folks expect of the poet to indicate more than the beauty and dignity which always attach to dumb real objects .... they expect him to indicate the path between reality and their souls." 28 It is not beauty, then, that is the poet's primary concern; throughout his life Whitman had little patience with conventional ideas of artistic beauty, feeling that they interfered with the simple clarity of statement that he valued above all. ${ }^{29}$

There is no beauty in "As I Ebb'd," at least not in any generally accepted sense; what there is in its place is a devotion to the ordinary, the plain, the un-beautiful, for these things, at least, can be trusted not to deceive. The universe may be beyond human comprehension, but the tufts of straw and limp blossoms washed up along the beach exist on a human scale and are accessible to human perception. Indeed, as the poem suggests, they are much like humans, insignificant and accidental. The problem for the poet, the artist, is to give significance to the insignificant and purpose to the accidental; and "As I Ebb'd" succeeds in doing precisely that, for as the ocean's debris provides an emblem of 
the human condition, it takes on importance. The point is to find the meanings of things within a human context; in that sense the poet can truly indicate a path between reality and the souls of his readers. In "Song of Myself" insignificant objects become significant insofar as they mirror the infinite cosmos; in "As I Ebb'd" they become significant insofar as they mirror the individual human soul. The dramatic shift in scale tells much about the magnitude of change taking place in the mind of the poet.

\section{University of Massachusetts}

\section{NOTES}

1 Prospectus to The Recluse, 58-59; The Norton Anthology of English Literature, ed. M. H. Abrams et al., 5th ed. (New York and London: W.W. Norton, 1986), 2:225.

2 "The Oven Bird," Complete Poems of Robert Frost (New York: Holt, Rinehart and Winston, 1949), 150.

3 The source for all quotations from Whitman's poetry and prose is Leaves of Grass, ed. Sculley Bradley and Harold W. Blodgett (New York: W.W. Norton and Company, 1973).

4 The Varieties of Religious Experience, 1902 (New York: New American Library, 1958), 163.

\section{The Varieties of Religious Experience, 163.}

6 In Walt Whitman's Poetry: A Psychological fourney (Boston: Houghton Mifflin Company, 1968), Edwin H. Miller characterizes the poem as "a kind of self-chastisement and fulfillment of the psychological cycle of guilt and punishment" (47). While the author's emphasis on a reversion to childhood, as opposed to falling into a state of depression, may be questioned, his comments, particularly on Whitman's humanity, are helpful.

7 Coleridge's lines in "Dejection: An Ode" are revealing: "I may not hope from outward forms to win / The passion and the life, whose fountains are within."

8 Here and elsewhere, "As I Ebb'd" may be profitably compared with Wordsworth's "Resolution and Independence," another poem in which the poet goes out walking and with astonishing suddenness falls into a mood of self-rebuke and dejection. Wordsworth also dismisses his poetry as naive and uninformed; and, like Whitman, he must learn the value of fortitude.

9 It is one sign of depression that those suffering from it tend to see their lives in terms of absolutes (e.g., "I've never done anything right"; "I always say the wrong things"). The individual whom William James quotes above goes on to say, "I have never done one act of duty in my life-sins against God and man, beginning as far as my memory goes back - a wildcat in human shape" (The Varieties of Religious Experience, 163). The intensity of the self-reproach ("I have never done one act of duty in my life") parallels Whitman's ("I have not once had the least idea who or what I am"; "I have not really understood any thing, not a single object"; emphasis added). A cognitive therapist would point out that the speaker must at least once have known himself or understood something, and very likely more than once. 
12 "East Coker," section III; T.S. Eliot, Collected Poems 1909-1962 (New York: Harcourt, Brace \& World, 1963), 187.

13 “East Coker," section III; Collected Poems, 187.

14 "Song of Myself," 1281.

15 In Whitman: Explorations in Form (Chicago and London: University of Chicago Press, 1966), 208, Howard J. Waskow comments that "Somewhere the poet gets his answer," but the evidence of the poem suggests otherwise. Were there an answer, we might expect an assertion of illumination, but there is none. When there is an answer in Whitman's poetry, the signs are clear.

16 As Richard Chase notes, this poem "expresses the final helplessness of man before the mystery of the universe" (Walt Whitman Reconsidered [New York: William Sloane, 1955], 124).

17 See, for example, "To You" (1856), 1; "Starting from Paumanok," 188-89; "Song of the Open Road," 189; "Whoever You Are Holding Me Now in Hand," 1; "Out from Behind this Mask," 15; "So Long!," 64; "Small the Theme of My Chant," 5. In "Song of Myself," 1321, Whitman calls out to his reader as "Listener up there!"

18 Whitman's most explicit statement of this theme comes in “A Backward Glance O'er Travel'd Roads," where the reader is seen as necessary not only to complete the process of poetic communication, but also-quite literally-to complete the poem itself: "I round and finish little, if anything; and could not, consistently with my scheme. The reader will always have his or her part to do, just as much as I have had mine. I seek less to state or display any theme or thought, and more to bring you, reader, into the atmosphere of the theme or thought-there to pursue your own flight" $(L G, 570)$.

19 The fullest and most intricate discussion of Whitman's relationship to his readers may be found in Kerry C. Larson, Whitman's Drama of Consensus (Chicago and London: University of Chicago Press, 1988). As Larson points out, "the only poem in the 1855 edition which does not begin by calling on its auditors" is "The Sleepers" (60).

20 The original title of "As I Ebb'd," it should be recalled, was "Bardic Symbols" - surely ironic, since the symbols of the poem are hardly "bardic."

21 "I returned, and saw under the sun, that the race is not to the swift, nor the battle to the strong, neither yet bread to the wise, nor yet riches to men of understanding, nor yet favour to men of skill; but time and chance happeneth to them all" (Eccles. 9:11).

22 “Song of Myself," 1157-1158.

23 In this respect "As I Ebb'd" may be profitably compared with Wordsworth's "Elegiac Stanzas," another poem that rejects a sustaining central vision discovered to be naive and at great psychic cost replaces it with darker and, to the poet, more truthful view of humanity's relationship to a nature now seen to be hostile.

24 James E. Miller, Jr., A Critical Guide to Leaves of Grass (Chicago and London: University of Chicago Press, 1957), 215.

25 As Jon Rosenblatt rightly comments, "It is crucial to Whitman's development that in 'As I Ebb'd' he admits that the natural universe, as well as the inner self, cannot find a unified, necessitated ground. The origins of self are random events over which we have 
no control; but we do know that the processes that govern our inner being are identical to the processes that govern the ebb and flow of life itself" ("Whitman's Body, Whitman's Language," in Walt Whitman Here and Now, ed. Joann P. Krieg [Westport, CT: Greenwood Press, 1985], 112).

26 "Song of Myself," 61. In its basic attitudes "As I Ebb'd" may be read as a commentary on "Song of Myself" and a correction of it.

27 The allusion, of course, is to The Waste Land, 431. It could be argued that the world of "As I Ebb'd" has much in common with Eliot's poem, particularly in its depiction of the breakdown of the poet's perceptions of order. Betsy Erkkila makes a similar connection in Whitman the Political Poet (New York and Oxford: Oxford University Press, 1989), 169, as she writes of Whitman's apprehension of "a collapsing civilization." In keeping with the theme of her book, Professor Erkkila's emphasis is political and historical, while this essay stresses the personal and psychological origins of the poem.

\section{$28 L G, 716$.}

29 See, for example, his statement in the 1855 Preface: "The greatest poet has less a marked style and is more the channel of thoughts and things without increase or diminution, and is the free channel of himself. He swears to his art, I will not be meddlesome, I will not have in my writing any elegance or effect or originality to hang in the way between me and the rest like curtains. I will have nothing hang in the way, not the richest curtains. What I tell I tell for precisely what it is" $(L G, 719)$. 